MERCADORIA PADRÃO E TAXA DE LUCRO: UMA CONTROVÉRSIA RECENTE

\author{
Homero Cuevas \\ Rodolfo Hof fmann w \\ Jean-Luc Rosingerws
}

RESUMO

No número de novembro de 1984 desta revista, foi publicada uma nota de $\mathrm{H}$. Cuevas intitulada "On Sraffa's 'Standard Commodity' and the Rate of Profit". Tal trabalho desencadeou uma polemica envolvendo diversos especialistas, que se posicionaram em desacordo com as conclusões de H. Cuevas. Tendo em vista a importãncía do te ma e o persistente debate em diversas notas que chegaram ao Editor da Revista de Econometria, resolvemos publicar aquelas notas que mais refletem o "estado da arte". Assim, nesse número temos o comentário inicial de $R$. Hoffmann, a réplica de $H$. Cuevas e tréplica de $R$. Hoffmann e a nota de $J$. Rosinger criticando a demonstraçāo de $\mathrm{H}$. Cuevas e acrescentando algumas observações a respeito do papel dos nāo-básicos na determinaçāo da taxa de lucro.

\title{
ABSTRACT
}

The November, 1984, issue of this Review published a note by H. Cuevas "On Sraffa's 'Standard Commodity' and the Rate of Profit" giving rise to a number of comments in disagreement with Professor

\footnotetext{
* Department of Economics, National University of Columbia, Bogotá.

University of Sāo Paulo - ESALQ, 1400, Piracicaba, SP. ixsis

Department of Economics, University of Brasilia.
} 
Cuevas conclusions. Given the relevance of the debate and the quality of the correspondence received by the Editor, the most representative notes are published in this issue of our Review of Econo metrics: R. Hoffmann's initial comment, H. Cuevas reply, R. Hoffmann's further comments and, finally, a note by $\mathrm{J}$. Rosinger which adds new observations regarding the role of non-basics in the determination of the rate of profit. 
COMENTÁRIO SOBRE UMA NOTA DE HOMERO CUEVAS

Rodolfo Hoffmann

Em uma nota publicada na Revista de Econometria 4(2), de novembro de 1984, Homero Cuevas contesta a afirmativa de sraffa no sentido de que as condições de produção das mercadorias nāo-bāsị cas nāo afetam a determinaçāo dos preços e da taxa de lucro. Na pá gina 125 sāo reproduzidos os seguintes trechos da obra de Sraffa:

"A partir da situaça em que toda a renda nacional vai para o trabalho, imaginemos que os salários sejam re duzidos: dessa forma surgiria uma taxa de lucros."

"Suponhamos que os preços permaneceram inalterados quando o salärio foi reduzido e surgiu uma taxa de lucros. Como, em qualquer indústria, o que seria poupado pela reduçào de salário dependeria do número de pessoas empregadas, enquanto o que seria necessário para pagar lucros a uma taxa uniforme dependeria do valor agregado dos meios de produçāo usados, as indústrias com uma proporçāo suficientemente baixa de trabalho em relaça a os meios de produçāo teriam um 'deficit', enquanto as indústrias com uma proporcão suficientemente alta de traba lho teriam um excedente, nos pagamentos por conta de salários e lucros."

Indicando por $\Delta v_{i}$ a reduçāo nos salários pagos na i-ésima indústria e indicando por $\mathrm{P}_{i}$ ○ montante de "lucros" que assim se or $\underline{i}$ gina, Cuevas escreve:

$$
\Delta \mathrm{V}_{i}=\mathrm{P}_{i}
$$


E claro que $\mathrm{P}_{i}$ nāo é o valor dos lucros que serāo realmente auferidos pelos capitalistas, pois, como está explícito no textode Sraffa citado, em geral haverá um déficit ou um superávit. Se indi carmos os lucros realmente auferidos (após o reajuste dos preços) por $\mathrm{P}_{i}^{*}$, temos em geral $\mathrm{P}_{i}^{*} \neq \mathrm{P}_{i}$.

Mais adiante Cuevas considera evidente que a taxa de lucros é igual à relaçāo entre o total de lucros e o valor total dos meios de produçāo, escrevendo

$$
r=\frac{\sum \mathrm{p}_{i}}{\sum \mathrm{K}_{i}}
$$

onde $\mathrm{K}_{\mathrm{i}}$ é o valor dos meios de produçāo na i-ésima indústria. Acon tece que essa relaçāo é verdadeira apenas se estivermos consideran do os lucros realmente auferidos. Assim, a relaçāo correta é

$$
r=\frac{\sum \mathrm{P}_{i}^{*}}{\sum \mathrm{K}_{i}},
$$

Dessa confusāo entre $\mathrm{P}_{i}$ (os "lucros" em uma situaçāo fictícia onde nāo há alteraçāo dos preços quando os salários diminuem) e $P_{i}^{*}$ (o valor efetivo dos lucros) decorrem as conclusões errõneas de Cuevas.

o exemplo numérico a seguir permite esclarecer a distinçāo entre $\mathrm{P}_{i}$ e $\mathrm{P}_{i}^{*}$. Consideremos uma economia ficticia extremamente sim ples onde há apenas duas indústrias: ferro e trigo. Uma tonelada de ferro é obtida utilizando-se 0,5 tonelada de ferro e 0,25 de $\underline{u}$ nidade de trabalho. Uma tonelada de trigo é obtida a partir de 0,5 tonelada de ferro e 0,75 de unidade de trabalho. De acordo com Sraffa, podemos escrever

$$
\left\{\begin{array}{l}
0,5 \pi_{1}(1+r)+0,25 w=\pi_{1} \\
0,5 \pi_{1}(1+r)+0,75 w=\pi_{2}
\end{array}\right.
$$

onde $\underline{w}$ é o salārio e $\pi_{1}$ e $\pi_{2}$ sāo os preços do ferro e do trigo, respectivamente. E claro que o trigo é um produto nāo-básico. 
o único produto básico é o ferro. Fazendo $\pi_{1}=1$ as equaçōes ficam

$$
\begin{aligned}
& 0,5(1+r)+0,25 w=1 \\
& 0,5(1+r)+0,75 w=\pi_{2}
\end{aligned}
$$

Note-se que a primeira equaçāo nos dá uma relaçāo w - r linear.

Quando toda a renda nacional vai para o trabalho temos $r=0$, $\mathrm{w}=2 \mathrm{e} \pi_{2}=2$.

Se o salário diminui para $w=1$, a nova situaçāo de equilíbrio ocorre com $r=0,5$ e $\pi_{2}=1,5$. O lucro na indústria de ferro será $\mathrm{P}_{1}^{*}=0,25$ e o lucro na indústria de trígo será $\mathrm{P}_{2}^{*}=0,25$. 0 total de lucros é $\sum \mathrm{P}_{\dot{i}}^{*}=0,5$ e o valor total dos meios de produçāo é $\Sigma \mathrm{K}_{\mathrm{i}}=1,0$, verificando-se que

$$
r=\frac{\sum \mathrm{P}_{i}^{*}}{\sum \mathrm{K}_{i}}
$$

Quando o salário diminui de $\mathrm{w}=2$ para $\mathrm{w}=1$ as reduções na folha de pagamentos sāo iguais a $\Delta v_{1}=0,25$ na indūstria de ferro e $\Delta v_{2}=0,75$ na indústria de trigo. Na primeira indústria essa re duçāo $\left(\Delta v_{1}=0,25\right)$ é exatamente suficiente para pagar a taxa de lucro de 50\% sobre o valor dos meios de produçāo. Temos $\Delta \mathrm{V}_{1}=\mathrm{P}_{1}$ $=\mathrm{P}_{1}^{*}=0,25$. Na indústria de trigo, entretanto, aquela reduçāo $(\Delta \mathrm{V}=0,75)$ leva a um excedente, pois temos

$$
\Delta V_{2}=P_{2}=0,75>P_{2}^{*}=0,25
$$

Esse excedente deixa de existir com a reduçāo do preço do trigo de $\pi_{2}=2$ para $\pi_{2}=1,5$.

Temos $\Delta \mathrm{V}_{1}+\Delta \mathrm{V}_{2}=\mathrm{P}_{1}+\mathrm{P}_{2}=\mathrm{P}=1$ e verifica-se que a relaçāo (2), utilizada por Cuevas, nāo é verdadeira. 
ON SRAFFA'S STANDARD COMMODITY AND THE RATE OF PROFIT:

ANSWER TO A CRITICAL NOTE

Homero Cuevas

1. PRELIMINAR DISCUSSION

First of all, it is necessary to point out that the identity between $\Delta \mathrm{V}_{i}$ and $\mathrm{P}_{i}^{*}$, for every $\underline{i}_{\text {, }}$ is not required for the argument under consideration:

By definition, $\Delta v_{i}=\alpha$. Li

(Where $\mathrm{Li}$ is the amount of labor employed in sector $\underline{i}$, and $\alpha=s^{\circ}-s^{\prime}$, that is, the difference between the original wage rate, when the totality of national income goes to wages, and the reduced wage rate).

Thus, $\quad \sum_{\Sigma}^{n} V_{i}=\alpha \cdot \sum_{\Sigma}^{n} L i$

On the other hand, payment of profits according to a general rate, i.e., with strict proportionality to capital invested within every sector, implies

$$
P_{i}^{*}=r \cdot K i
$$

where $P_{i}^{*}$ stands for the profits of sector $i$ 's, if those were paid at the general rate, $r$.

Therefore, ${ }_{\Sigma}^{n} P_{i}^{*}=r \cdot{ }_{\Sigma}^{n} K i$

From $(4): \frac{\sum_{i}^{n} \mathrm{P}_{i}^{*}}{\sum_{\mathrm{K}} \mathrm{Ki}}=r$

Now, according to sections 15, 16 an 17 of Sraffa's book, any "balancing" sector has the property that "the proceeds of the wage 
reduction would provide exactly what was required for the payment of profits at the general rate". That is:

$$
\mathrm{P} \stackrel{*}{\mathrm{~b}}=\Delta \mathrm{Vb}
$$

where $b$ identifies the given "balancing" sector.

$$
\begin{aligned}
& \text { Replacing (1) and (3) into (6): } \\
& \text { r. Kb }=\alpha \text {. Lb }
\end{aligned}
$$

and replacing (5) into (7):

$$
\frac{\sum_{\Sigma}^{\mathrm{n}} \mathrm{Pi}^{*}}{\mathrm{n} \mathrm{Ki}} \cdot \mathrm{Kb}=\alpha \cdot \mathrm{Lb}
$$

That i.s:

$$
\frac{\sum_{\sum}^{n} P_{i}^{*}}{\sum_{i}}=\alpha \cdot \frac{L b}{K b}
$$

Now, "starting from the situation in which the whole of the national income goes to labour", the only amount available for the payment of profits at the general rate, within the system as a whole, is the amount saved as a result of the wage-reduction. Thus:

$$
{ }_{\Sigma}^{\mathrm{n}} \mathrm{Pi}={ }_{\Sigma}^{\mathrm{n}} \Delta \mathrm{Vi}=\alpha \cdot{ }_{\Sigma}^{\mathrm{n}} \mathrm{Li}
$$

And, replacing (10) into (9):

$$
\alpha \cdot \frac{\sum^{n} \mathrm{Li}}{\sum^{n} \mathrm{Ki}}=\alpha \cdot \frac{\mathrm{Lb}}{\mathrm{Kb}} \text {, or } \frac{\sum_{\sum}^{n} \mathrm{Li}}{\sum^{n} \mathrm{Ki}}=\frac{\mathrm{Lb}}{\mathrm{Kb}}
$$

\footnotetext{
*

$\sum^{n} V i=\alpha \cdot \sum_{\Sigma}^{n} L i$, according to eq. (2).
} 
Thus, sraffa's definition of a "balancing" proportion boils down to an identity with the proportion of labor to means of production of the economy as a whole. (From this point on, the argument remains unchanged).

\section{FURTHER DISCUSSION}

Before further discussion, it is necessary to remind Sraffa's own definition of a balanced industry. In fact, in sections 16 and 17 of his book, the condition" that prices did remain unchanged when the wage was reduced and a rate of profit emerged" is the very basis of such a definition. The following are the relevant sections:

"16 For the same reason it is impossible for prices to remain unchanged when there is inequality of 'proportions'. Suppose that prices did remain unchanged when the wage was reduced and a rate of profits emerged. Since in any one industry what was saved by the wage-reduction would depend on the number of men employed, while what was nee ded for paying profits at a uniform rate would depend on the aggregate value of the means of production used, industries with a sufficiently low proportion of labour to means of production would have a deficit, while industries with a sufficiently high proportion would have a surplus, on their payments for wages and profits. (Nothing is assumed at the moment as to what rate of profits corresponds to what wage reduction; all that is required at this stage is that there should be a uniform wage and a uniform rate of profits throughout the system.)

17 There would be a 'critical proportion' of labour to means of production which market the watershed between 'deficit'and 
'surplus' industries. An industry which employed that particular 'proportion' would show an even balance - the proceeds of the wage-reduction would provide exactly what was required for the payment of profits at the generalra te. Whatever the precise value of that 'proportion' in any particular system, it can be said apriori that, in a system including two or more basic industries: the industry with the lowest proportion of labour to means of production would be a 'deficit' industry and the one with the highest proportion would be a 'surplus' industry."

Thus, if Sraffa's own definition is adopted, it is necessary to see what happens to the numerical example in the critical note when "prices did remain unchanged when the wage was reduced and a rate of profits emerged":

$$
\begin{aligned}
& 0,5 \pi_{1}(1+r)+0,25 w=\pi_{1} \\
& 0,5 \pi_{1}(1+r)+0,75 w=\pi_{2}
\end{aligned}
$$

where, according to Sraffa's words, industry 1 (iron) is a deficit industry, whilst industry $\underline{2}$ (wheat) is a surplus industry. Clearly, starting from a situation of zero profits $(r=0)$ and $\underline{w}=2$, if prices did remain unchanged when $w$ is reduced to 1 , following the figures of the critical note, savings amount to:

$$
\begin{aligned}
v_{1} & =0,25 \\
v_{2} & =0,75 \\
\Sigma v_{i} & =1,00
\end{aligned}
$$

Now, following Sraffa's words, if "prices did remain unchanged", "what was needed for paying profits at a uniform rate would" be 0,50 for industry 1 and 0,50 for industry $\underline{2}$, because the amount of capital invested is the same in both industries. This is why "the industry with the lowest proportion of labour to means of productions would be a 'deficit' industry and the one with the highest proportion would be a 'surplus' industry". The fact that these a- 
mounts of profits become reality or not is out of the question. In other words, the fact that sraffa's own definition is based upon a hipothetical sitlation does not change sraffa's own definition. The whole issue would be more clear if we make explicit whether we are accepting Sraffa's definitions or we are changing them. On my part, I start from the first alterntive because the precise objective of my note was to show that sraffa was victim of a contradiction in terms of his own logic.

It follows, obviously, that the contents as well as the preci sion of such a definition is totally independent from the amount of profits which "actually" accrue to the iron and wheat industries. This is why, for the discussion under way, it does not matter whether we call "profit" the amount saved within each industry ( $\mathrm{V} i$ ) or the amount which would accrue to each of them ( $P_{i}^{*}$ ). As the nume rical example shows, the total amount of savings that sprang from the wage reduction is identical with the total amount of profits which would accrue to the industries as a whole, and this is all what is required for the validity of the conclusion in section $I$ ), as the set of equations shows.

3. COMPLETING THE ARITHMETICAL EXAMPLE

The purpose of section II is not, of course, to avoid a dis-. cussion about the relationship between $\sum \mathrm{V} i$ and $\Sigma \mathrm{P} i$ when prices do change in face of a wage reduction. But, as in the case of section I), before going to this issue, it is necessary to make sure that Sraffa's internal logic is preserved. Thus, let us listen to Sraffa's own words about the right procedure to examine the efects upon his model of a change in the wage-rate, when prices are allowed to change:

\section{THE STANDARD COMMODITY}

"23 The necessity of having to express the price of one commodity in terms of another which is arbitrarily chosen 
as standard, complicates the study of the pricemovenents which accompany a change in distribution. It is impossible to tell of any particular price-fluctuation whether it arises from the peculiarities of the commodity which is being measured or from those of the measuring standard. The relevant peculiarities, as we have just seen, can only consist in the inequality in the proportions of labour to means of production in the sucessive 'layers' into which a commodity and the aggregate of its means of production can be analysed; for it is such an inequality that makes it necessary for the commodity to change in value relative to its means of production as the wage changes.

The 'balanced' commodity which we have just considered ( $\$ 21$ ) would present no peculiarities of this type, since the same proportion would be found in all its 'layers'. It is true that, as wages fell, such a commodity would be no less susceptible than any other to rise or fall in price relative to other individual commodities; but we should know for certain that any such fluctuation would originate exclusively in the peculiarities of production of the commodity which was being compared with it, and not in its own. If we could discover such a commodity we should therefore be in possession of a standard capable of isolating the price-movements of any other product so that they could be observed as in a vacuum."

"21 We now revert to the 'critical' proportion which has been mentioned before $(\$ 17)$ as constituting the border line between 'deficit' industries and 'surplus' industries. Suppose that there was an industry which employed labour and means of production in that precise proportion, so that with a wage-reduction, and on the basis of the initial prices, it would show an exact balance of wa ges and profits. Suppose further that the means of production which it used, taken as an aggragate, were them selves produced by labour and means of production in that 
proportion; and suppose finally that the same proportion applied to the proctuction of the aggregate means of production by which those means of production were produced, and similarly to the sucessive layers of means of production involved, however far we traced them back.

The commodity produced by such an industry would be under no necessity, arising from the conditions of production of the industry itself, either to rise or to fall in value relative to any other commodity when wages rose or fell; for, as we have seen, a necessity of this sort can originate only from a potential deficit or surplus and an industry operating under the conditions described would ipso facto be in balance. A commodity of this type would in any case be incapable of changing in value rela tive to the aggregate of its own means of production sin ce the recurrence of the same 'proportion' would apply equally to them.

Two separate conditions have been assumed to obtain this result, namely (1) that the 'balancing' proportion is used, and (2) that one and the same proportion recurs in all the successive layers of the industry's aggregate means of production without limit. We shall, however, find that the first condition is necessarily implied in the second for, as will presently appear ( 22 ), within any one system complete 'recurrence' is only possible with the balancing proportion. So that there is in effect only one condition, that of 'recurrence'."

Therefore, for the examination of changes in income distribution when prices are allowed to change, sraffa rejects explicitly any standard of prices "arbitrarily chosen", i.e., any arbitrary numeraire. This forces him to the task of building his "standard commodity", to which he dedicates the whole of chapters III, IV and $V$. This is not a gratuitous work, for sraffa simply follows Ricardo in the search for an invariable standard, based upon Ricar do's demonstration that any analysis of income distribution without 
this standard would be merely misleading. In section 21 of his book, Sraffa describes the required peculiarities of this standard. Simply, it. should fulfill the condition of "recurrence" of a balanced proportion of labour to means of production, and similarly in all "the successive layers of means of production involved". According to this, the arithmetical example of the critical note has to be completed with a sraffian standard commodity. This is shown below:

$$
\begin{aligned}
& 0,5 \pi_{3}(1+r)+0,25 w=\pi_{1} \\
& 0,5 \pi_{3}(1+r)+0,75 w=\pi_{2} \\
& 0,5 \pi_{3}(1+r)+0,50 w=1,5 \pi_{3}
\end{aligned}
$$

It can be easily shown that sector 3 is a sraffian standard Commodity. In the first place, it is a balanced sector because, going back to the example of section II), sector 3 would be the only one in the economy without a surplus or a deficit, when the wage rate is reduced from 2 to 1 and "prices did remain unchanged". Indeed, $\Delta v_{3}=0,50$ and this is exactly what is required to pay its profit at the general rate. And, in the second place, the sraf fian "recurrence" condition in all "the successive layers of means of production involved" is guaranteed by the fact that sector 3 is the only one which produces means of production, for all remaining sectors and for itself.

Now, adopting the Sraffian standard, that is, the price of sector 3 , i.e., making $\pi_{3}=1$, and starting from a situation of $z$ e ro profits, i.e, $r=0$, the values which solve the above system of equations are: $w=2 ; \pi_{1}=1$ and $\pi_{2}=2$.

When the wage-rate is reduced to 1 , following the numbers of the critical note, and the same standard is conserved, the solutions are: $r=1 ; \pi_{1}=1,25$ and $\pi_{2}=1,75$. According to this, actual profits are: $\mathrm{P}_{1}^{*}=0,50 ; \mathrm{P}_{2}^{*}=0,50$ and $\mathrm{P}_{3}^{*}=0,50$. Savings obtained from the wage reduction are: $\Delta V_{1}=0,25 ; \Delta V_{2}=0,75$ and $\Delta V_{3}=0,50$.

Thus, again, it is demonstrated that, following sraffa's model, the total sum of actual profits is identical to the total sum 
of savings obtained from the wage reduction; even if prices are al lowed to change, although this is not required for the definition of the balanced sector.

When the same process is repeated using $z$ spurious standard, the logical result is a difference between $\sum \Delta V i$ and $\sum \mathrm{P} i$. For $_{\star}^{i n s}$ tance, making $\pi_{2}=1$, it is obtained that $\sum \mathrm{Vi}=0,750$ and $\sum \mathrm{Pi}=$ 1,00 . But this only proves the misleading distortions of the spurious standard, which forced Ricardo and sraffa into the very hard task of searching for the perfect standard commodity.

\section{CONCLUSIONS}

The arbitrary adoption of any price as numeraire, i.e., as standard of the remaining prices, can be a logical step within the neoclassical framework. But, of course, this is not the case within the Sraffian framework. As sraffa himself stated, for a correct analysis of income distribution using his model, it is crucial to know that the relative price variations of the standard "originate exclusively in the peculiarities of the commodity which was being compared with it, and not in its own". (Naturally, these different positions about the standard are related to the fact that sraffa does not adopt the production function as the basis of his analysis of income distribution).

Thus, the basic mistake of the critical note is that, arbitra rily, it adopts as standard of the sraffian model the price of the iron industry, $i . e$, it makes $\pi_{1}=1$, when this industry is very far removed from being a balanced industry, and even farther from being a sraffian standard commodity. This spurious standard could not but produce a misleading result. 
COMENTÁRIOS SOBRE A RESPOSTA DE CUEVAS

Rodolfo Hoffman

Cuevas termina sua "Resposta" ao meu "Comentário" afirmando que meu erro básico foi fixar "arbitrariamente" o preco do ferro $\left(\pi_{1}=1\right)$ no exemplo que apresentei. Esse exemplo consiste nas seguintes equações:

$$
\begin{aligned}
& 0,5 \pi_{1}(1+r)+0,25 w=\pi_{1} \\
& 0,5 \pi_{1}(1+r)+0,75 w=\pi_{2}
\end{aligned}
$$

A primeira equaçāo representa a indústria de ferro e a segunda equaçāo corresponde à produçāo de trigo. Nesse sistema a única mercadoria básica é o ferro, que é entāo, obviamente, a mercadoria padrāo. Entretanto, Cuevas afirma que, nesse exemplo, o ferro nāo é, de acordo com Sraffa, a mercadoria padrāo. Um de nós nāo entendeu o que é a mercadoria padrāo em sraffa.

Estou de acordo com as equações (1) a (9) na "Resposta" de Cuevas, ressaltando que as equações (6) a (9) só serāo válidas, em geral, se a mercadoria padrāo for utilizada como unidade de medida dos preços. Mas entāo discordo da sua equaçāo (10), de acordo com a qual teríamos:

$$
\sum \mathrm{P}_{i}^{*}=\Sigma \Delta \mathrm{V}_{\mathrm{i}}
$$

onde $\sum \mathrm{P}_{i}^{*}$ é o total dos lucros e $\sum \Delta \mathrm{V}_{i}$ é a reduçāo no pagamento total de salários, partindo-se da situaçāo em que a taxa de lucros é igual a zero e todo o produto liquido é apropriado pelos traba lhadores.

A tabela a seguir mostra os valores das grandezas econômicas fundamentais para o exemplo acima, considerando trēs valores para a taxa de lucros e sempre fixando $\pi_{1}=1$, isto é, tomando como un dade de preço a tonelada de ferro, que é a mercadoria padrāo do sistema. 


\begin{tabular}{|c|c|c|c|c|c|c|c|}
\hline $\begin{array}{c}\text { Taxa de } \\
\text { Lucro } \\
(r)\end{array}$ & $\begin{array}{c}\text { Salärio } \\
\text { (w) }\end{array}$ & $\begin{array}{c}\text { Preço do } \\
\text { Trigo } \\
\mathbb{I}_{2}\end{array}$ & $\begin{array}{c}\text { Lucro } \\
\text { total } \\
\sum P \text { 㽜 }\end{array}$ & $\begin{array}{c}\text { Total de } \\
\text { Salários } \\
\sum V_{i}\end{array}$ & $\Sigma$ & $\Delta$ & $v_{i}$ \\
\hline 0 & 2 & 2 & 0 & 2 & & - & \\
\hline 0,5 & 1 & 1,5 & 0,5 & 1 & & 1 & \\
\hline 1 & 0 & 1 & 1 & 0 & & 2 & \\
\hline
\end{tabular}

Verifica-se que $\sum_{i}^{*} \neq \sum \Delta V_{i}$

Há igualdade entre $\mathrm{P}^{\star} \mathrm{e} \Delta \mathrm{V}$ apenas na indústria que produz a mercadoria padrão, como se pode verificar na tabela a seguir:

\begin{tabular}{cccc}
\hline $\begin{array}{c}\text { Taxa de } \\
\text { Lucro } \\
(\mathrm{r})\end{array}$ & Indústria de & Ferro (mercadoria padrão) \\
\cline { 2 - 4 } & Lucro & Salärios & $\Delta v_{1}$ \\
\hline 0 & Pri & $v_{1}$ & - \\
0,5 & 0 & 0,5 & 0,25 \\
1 & 0,25 & 0,25 & 0,5 \\
\hline
\end{tabular}

Cuevas parece achar evidente que $\sum P_{i}^{*}$ deva ser igual a $\Sigma \Delta V_{i}$, pois o único montante disponível para o pagamento dos lucros, no sistema como um todo, seria o que foi "poupado" com a redução do salário. Isso seria verdade se estivéssemos considerando o produto líquido em termos físicos, se estivéssemos medindo os valores em tempo de trabalho ou se fixássemos o preço da mercadoria lou conjunto de mercadorias) que forma o produto líquido. Mas se utilizamos a mercadoria padrão como unidade de medida dos preços, temos, em geral, $\sum \mathrm{P}_{i}^{\star} \neq \sum \Delta \mathrm{V}_{i}$, devido à variação do valor monetário do produto líquido.

Cuevas apresenta um exemplo numérico com 3 indústrias para o qual $\sum \mathrm{P}_{i}^{*}=\sum \Delta \mathrm{V}_{i}$. Nesse exemplo também há apenas uma mercadoria básica, que é a produzida na 3ă indústria. Conseqlentemente, essa é 
a mercadoria padrão. O exemp lo de Cuevas é construído de tal manei ra que:

$$
\frac{\sum L_{i}}{\sum K_{i}}=\frac{L_{b}}{K_{b}} \text {, }
$$

que é exatamente o resultado que o autor pretende ter demonstrado no final da p.2 de sua "Resposta".

Quando se quer mostrar que uma igualdade não é sempre verdadei ra, basta apresentar um exemplo onde a igualdade não ocorre. Infelizmente para Cuevas, é mais difícil provar que uma igualdade é, em geral, válida.

$$
--0-\cdots
$$

TAXA DE LUCRO E BENS NÃO-BÁSICOS EM UM MODELO SRAFFIANO DE PRECOS DE PRODUCÃO: UIMA RESPOSTA AO SR, CUEVAS

$$
\text { Jean-Luc'Rosinger }
$$

\section{INTRODUCR̃O}

Em uma nota publicada recentemente nesta revista (Cuevas, 19841 , O Sr. Cuevas pretende estabelecer algumas proposiçōes surpreendentes para os leitores familiarizados com o modelo simples de preços de produção de Piero Sraffa. Segundo o Sr. Cuevas (1984: 128, tradução nossa):

"... a deduçào de Sraffa que "sua presença ou ausēncia [dos não-básicos] não faz nenhuma diferença para a deter minação dos preços" é errada. E porque a exclusão dos não -básicos modifica os preços dos básicos, e porque a taxa de lucro depende explicitamente dos últimos, é evidente que a exclusảo dos não-básicos do sistema original modifica também a taxa de lucro". 
A argumentação do Sr. Cuevas fundamentamse sobre uma demonstrą ção de que a ausēncia dos bens não-básicos no sistema-padrão de Piero Sraffa (o setor com a "proporção balanceada", Cuevas 1984:12 $\underline{5}$ -126) implica que a taxa de lucro neste sistema é diferente da taxa de lucro no sistema original, o qual inclui os bens básicos (Cue vas, $1984: 125-129$ ).

As consequências deste resultado inédito são desastrosas para as proposições de Piero Sraffa; de uma forma mais geral, elas afetariam toda a lógica da determinação dos preços de produção, tal como ela foi desenvolvida por numerosos autores desde Dmitriev.

Nesta nota, mostraremos que a demonstração do Sr. Cuevas está errada, antes de propor um exemplo ilustrando o erro. Concluiremos com algumas observações a respeito da não influência dos métodos de produção dos bens não-básicos sobre a taxa de lucro.

\section{ALGUMAS RELACOES FUNDAMENTAIS}

A demonstração do Sr. Cuevas está errada. Ela envolve confusões entre agregados avaliados a preços de equilíbrio e a preços fora-equilibrio; confusões paradoxais em se tratando de una crítica à obra de Piero Sraffa, que se dedicou ao estudo das variações dos preços em função de alterações na distribuição do produto.

Cremos indispensável, para a claridade da demonstração de nossa afirmação, relembrar algumas relações básicas entre salārios, lucros e preços dos meios de produção. A confrontação destas relações com as asserções do Sr. Cuevas permitirá então identificar as confusões deste. Seguiremos o raciocínio proposto por Piero Sraffa no capítulo 3 de "Produção de Mercadorias por Meio de Mercadorias", ponto de partida da demonstração do Sr. Cuevas Utilizaremos a formalização habitual dos modelos de preços de produção, necessária pa ra evitar deslizes com consequências fatais. Sejam portanto: 
A a matriz dos cceficientes técnicos de produção, decompon $\underline{i}$ vel e produtiva.

$A_{1}^{1}$ a submatriz de A correspondendo aos coeficientes dos bens básicos, quando a matriz A é reordenada efetuando as permutaçōes de linhas e colunas permitindo sua decomposição.

1 o vetor (linha) das quantidades de trabalho por unidade de produto.

p o vetor (linha) dos preços.

$l_{1}, p^{1}$ os vetores (linha) respectivamente das quantidades de trạ balho e dos preços correspondendo aos bens básicos.

$x$ ○ vetor (coluna) das quantidades produzidas.

$z$ o vetor (coluna) das proporçōes do sistema-padrão.

w a taxa dos salários.

$r$ a taxa de lucro.

R a taxa máxima de lucro.

Inicialmente, todo o produto líquido do sistema original é destinado aos salários; a taxa de lucro é, portanto, nula. Chamando a taxa dos salários, nesta situaçāo, de $w_{0}$, e o vetor dos preços de equilíbrio de $\mathrm{p}_{\mathrm{O}}$, temos:

$$
w_{0} l x=p_{0}(I-A) x
$$

No sistema-padrão, temos analogamente:

$$
w_{0}{ }^{\hat{l}} z=p_{0}^{1}\left(I-A_{1}^{1}\right) z
$$

Preços e salários são medidos no mesmo numerário, no sistema original como no sistema-padrão. Escolhemos o preço do produto líquido padrão como padrão dos preços (isto é, $\mathrm{p}^{1}\left(I-\mathrm{A}_{1}^{1}\right) z=1$ ).

Suporemos agora que a taxa dos salários é diminuída de $\Delta \mathrm{w}$, sen do agora $w_{1}$. Por definição, as relaçōes (1) e (2) podem ser respec tivamente reescritas assim:

$$
\left(w_{1}+\Delta w\right) l x=p_{0}(I-A) x
$$




$$
\left(w_{1}+(\Delta W)\right]_{1} z=p_{0}^{1}\left(I-A_{1}^{1}\right) z
$$

A "deduçāo" sobre os salários permite o surgimento de uma taxa de lucro positiva. Esta taxa, $r$, pode ser expressa tanto no sis tema original como no sistema-padrāo. No primeiro, temos:

$$
r=\frac{p_{1}(I-A) x-w_{1} l x}{p_{1} A x}
$$

no sistema-padrāo:

$$
r=\frac{p_{0}^{1}\left(I-A_{1}^{1}\right) z-w_{1}{ }_{1} z}{p_{0}^{1} A_{1}^{1} z}
$$

se chamamos de $p_{1} \circ$ vetor dos preços correspondendo à nova taxa de salários $w_{1}$. Lembrando (4), temos, portanto, no sistema-padrāo:

$$
r=\frac{\Delta w l_{1} z}{p_{O}^{1} A_{1}^{1} z}
$$

Observemos que, neste sistema, a taxa de lucro de equilíbrio é avaliada a partir dos preços iniciais $\mathrm{p}_{0}$. Mais geralmente, ela pode ser calculada a partir de qualquer conjunto de preços, conquanto que o salário seja medido em produto líquido padrāo. o sistema-padrāo é - como é bem conhecido - a indústria apresentando a "proporçāo crítica" entre trabalho e meios de produçāo evocada por Piero Sraffa (1960:13, parágrafo 17).

Para discutir as asserçōes do Sr. Cuevas, é necessário propor uma razāo de preços particular, calculada no sistema original a partir dos preços iniciais $\mathrm{p}_{0}$. Chamaremos esta razāo de "pseudo ta xa de lucro", $r^{\mathrm{ps}}$ :

$$
x^{p s}=\frac{p_{0}(I-A) x-w_{1} l_{x}}{p_{0} A x}
$$

Temos, entāo, a partir de (3): 


$$
r^{p s}=\frac{\Delta w \cdot 1 x}{p_{O}^{A x}}
$$

Finalmente, definindo $\Delta w^{\prime}$ de maneira que a relaçāo seguinte:

$$
\left(w_{1}+w^{\prime}\right) l x=p_{1}(I-A) x
$$

seja verificada, a taxa de lucro de equilibrio pode ser reescrita, no sistema original, na forma de uma razāo semelhante às razōes (7) e (8). A partir de (5), temos com efeito:

$$
r=-\frac{\Delta w^{\prime} \cdot I x}{p_{1} A x}
$$

Ao cabo deste exercício, temos trēs razōes: a taxa de lucro de equilíbrio nas expressōes (7) e (10), e uma "pseudo taxa de lucro" na expressāo (8), as quais permitem apontar as cónfusōes da demonstraçāo do Sr. Cuevas.

O que é que o Sr. Cuevas afirma? No sistema-padrāo, ele conce de que a deduçāo sobre os salários originais permite a taxa de lucro de equilíbrio sem mudanças dos preços (1984:126, relaçāo (3)). Em outras palavras, ele concordaria com nossa relaçāo (7). Algumas linhas abaixo, porém, aparece uma relaçāo inesperada. Tendo lembra do que a taxa de lucro é a razāo entre os lucros e o preço dos meios de produçāo, ele escreve (1984:127, relaçāo (9)):

$$
\frac{\Delta w \cdot d x}{p_{0} A x}=\frac{\Delta w \cdot 1_{1} z}{p_{0}^{1} A_{1}^{1} z}
$$

Esta relaçāo é evidentemente falsa. Este erro conduz o Sr. Cuevas a uma conclusāo inédita: que a "definiçāo de sraffa de uma proporçāo "balanceada" ou "crítica" reduz-se a uma identidade com a proporçāo entre o trabalho e os meios de produçāo na economia co mo um todo" (1984:127). Examinemos de mais perto estes resultados surpreendentes.

O Sr. Cuevas confundiu a relaçāo correta entre a taxa de lucro no sistema-padrāo e a taxa de lucro no sistema original: 


$$
\frac{w^{\prime} \cdot 1 x}{p_{1} A x}=\frac{l_{W} \cdot 1_{1} z}{P_{O}^{1} A_{1}^{1}}
$$

isto é, a relaçāo de igualdade entre as expressōes (10) e (7), com uma relaçāo inexistente entre a taxa de lucro de equilibrio (expressāo (10) ou (7)) e nossa "pseudo taxa de lucro" (expressāo (8)), a reliaçāo (11). Tivesse ele considerado a relaçāo correta (12), ele nāo poderia ter obtido sua conclusāo a respeito da "proporçāo balanceada", conclusāo que se escreve, a partir de (11):

$$
\frac{1 x}{p_{0} A x}=\frac{11^{2}}{p_{0}^{1} A_{1}^{1} z}
$$

Esta relaçāo entre a "proporçāo balanceada", $\frac{\mathrm{l}_{1} z}{\mathrm{P}_{0}^{1} \mathrm{~A}_{1}^{1} z}$, e a "pro porçāo entre o trabalho e os meios de produçāo na economia como um todo", $\frac{1 \mathrm{x}}{\mathrm{P}_{\mathrm{O}} \mathrm{A}_{\mathrm{x}}}$ inexiste. A partir da relaçāo verdadeira (12), nāo po demos dividir os dois membros pela reduçāo dos salários, como o fez o Sr. Cuevas (1984: 127, relações (9) e (10)). A deduçāo sobre os salários iniciais no sistema-padrāo, $\Delta w$, que proporciona os lucros còrrespondendo à taxa de lucro de equilibrio preços iniciais por nāo proporciona os lucros correspondendo a esta taxa no sistema original. No sistema original, esta deduçāo deve ser avaliada a partir dos novos preços de equilíbrio, $p_{1}$, e será dada por $\Delta w^{\prime}$ (ver expressāo (9)). Neste sistema, como Piero sraffa o explica enfaticamente, as variações de preços consecutivas a uma variaçāo na dis tribuiçāo tēm como resultado de "reestabelecer o equilíbrio em cada indústria" (1960:15, parágrafo 20); a taxa de lucro de equilibrio é dada pela expressāo (10) e nāo pela expressāo (8).

A "proporçāo crítica" de Sraffa NÃ é a "proporçāo entre o trabalho e os meios de produçāo na economia como um todo"; ela é a proporçāo entre o trabalho direto e o trabalho indireto no sistema -padrāo, nunca igual (exceto caso particular) a esta proporçāo no sistema original. Sabemos, com efeito, que a "proporçāo crítica" é igual à taxa máxima de lucro $R$ (Sraffa, 1960: 17, parágrafo 22). ora, como é bem conhecido:

$$
A_{1}^{1} z=\frac{1}{1+R} z
$$


portanto:

$$
R=\frac{p_{0}^{1}\left(I-A_{1}^{1}\right) z}{p_{0}^{1} A_{1}^{1} z}
$$

e como:

$$
\mathrm{p}_{0}^{1} \mathrm{~A}_{1}^{1} \mathrm{z}+\mathrm{I}_{1} \mathrm{z}=\mathrm{p}_{0}^{1} \mathrm{z}
$$

temos:

$$
\frac{p_{0}^{1}\left(I-A_{1}^{1}\right) z}{p_{0}^{1} A_{1}^{1} z}=\frac{l_{1} z}{p_{0}^{1} A_{1}^{1} z}
$$

Em palavras, a "proporçāo crítica", igual a R, é igual à ra$z$ āo entre o trabalho direto $(1, z)$ e o trabalho indireto $\left(\mathrm{p}_{0}^{1} \mathrm{~A}_{1}^{1} z\right.$, preço dos meios de produçāo quando todo o produto líquido é destinado aos salários, proporcional neste caso ao valor-trabalhol no sistema-padrāo. No sistema oriọinal, esta "proporçāo crítica" será igual a uma razāo de preços - e nāo de quantidades (de trabalho)-, a razāo entre o preço do produto líquido e o preço dos meios de produçāo quando a taxa dos salários é nula e a taxa de lucro máxima.

O que resta de todas as proposiçōes ulteriores da nota do Sr. Cuevas? A chave de suas asserçōes - a suposta relaçāo (13) - sendo errada, como acabamos de prová-lo, devemos deduzir que todas as suas proposiçōes subsequentes, derivadas deste resultado, sāo também erradas. O "Prelúdio a uma Crítica da Economia Política" merece leitores menos apressados "(ou menos dogmáticos?)".

3. UM EXEMPLO NUMERICO

Um exemplo simples ilustrará nossas asserçōes. Trēs ināútrias $(j=1,2,3)$ produzem três mercadorias $(i=1,2,3)$; as mercadorias 
1 e 2 sāo básicas, a terceira é nāo-bāsica. A descriçāo deste sistema econômico è a seguinte:

0,4 (mercadoria 1); 0,2 (mercadoria 2); 0,4 (trabalho) +1 (mercadoria 1)

0,3 (mercadoria 1);0,2 (mercadoria 2); 0,4 (trabalho) $\rightarrow 1$ (mercadoria 2)

0,3 (mercadoria 2); 0,2 (trabalho) +1 (mercadoria 3)

Utilizando a notaçāo do item anterior, temos:

$$
\begin{aligned}
& A=\left[\begin{array}{lll}
0,4 & 0,3 & 0 \\
0,2 & 0,2 & 0,3 \\
0 & 0 & 0
\end{array}\right] \\
& x^{\prime}=\left[\begin{array}{lll}
1 & 1 & 1
\end{array}\right]
\end{aligned}
$$

e a submatriz A ${ }_{1}^{1}$ correspondendo aos bens básicos é:

$$
A_{1}^{1}=\left[\begin{array}{ll}
0,4 & 0,3 \\
0,2 & 0,2
\end{array}\right]
$$

cuja raíz de Frobenius é $\lambda\left(A_{1}^{1}\right)=0,5646$. A taxa de lucro máxima do sistema, calculada a partir de $\lambda\left(A_{1}^{1}\right)$, será: $R=0,7712$. O vetor $z$ dos multiplicadores do sistema-padrāo (escolhido de maneira que o sistema-padrāo utilize todo o trabalho do sistema original, isto é, tal que $l_{1} z=1$ ) é:

$$
z^{\prime}=\left[\begin{array}{ll}
1,6144 & 0,8856
\end{array}\right]
$$

o produto-líquido padrāo, numerário dos preços, é o vetor:

$$
\left(\left[I-A_{1}^{1}\right] z\right)^{\prime}=\left[\begin{array}{ll}
0,703 & 0,3856
\end{array}\right]
$$

Inicialmente, quando todo o produto líquido do sistema é destinado aos salários, o vetor dos preços $p_{0}$ é:

$$
\mathrm{p}_{0}=\left[\begin{array}{lll}
0,9524 & 0,8571 & 0,4571
\end{array}\right]
$$

(com, por definiçāo, $w_{0} l x=1$ e $\left.\mathfrak{D}_{0}[I-A] x=1\right)$. 
Supondo agora uma dedução sobre os salários originais de:

$$
\Delta w_{.}=0,8051
$$

isto é, uma taxa dos salários de (medida em produto-líquido padrão) :

$$
\mathrm{w}_{1}=0,1949
$$

o vetor dos preços, medidos em produto líquido padrão, será:

$$
p_{1}=\left[\begin{array}{lll}
0,9746 & 0,8166 & 0,4361
\end{array}\right]
$$

o produto líquido original tem então como preço:

$$
P_{1}[I-A] x=0,9735
$$

e, nesta situação, a dedução sobre os salários $\Delta w^{\prime}$ se torna igual a:

$$
\Delta w^{\prime}=p_{1}[I-A] x-w_{1} l x=0,7785
$$

A taxa de lucro de equilíbrio no sistema original é:

$$
r=\frac{\Delta w^{\prime} \cdot 1 x}{p_{1} \cdot x_{x}}=0,6209
$$

No sistema padrão esta taxa é dada por:

$$
r=\frac{\Delta w \cdot I_{1} z}{p_{0}^{1} A_{1}^{1} z}=0,6209
$$

enquanto que a "pseudo taxa de lucro" é:

$$
r^{p s}=\frac{\Delta w \cdot 1 x}{P_{0} A x}=0,6356^{\circ}
$$

Verifica-se que $r^{\mathrm{ps}}$ é diferente de $r$.

Pode ser verificado também que a "proporção crítica", igual a $R$, é igual à razão entre a quantidade de trabalho direto e a quan- 
tidade de trabalho indireto no sistema-padrāo. De fato:

$$
\frac{1_{1} z}{P_{O}^{1} A_{1}^{1} z}=\frac{1}{1,2966}=0,7712
$$

e já calculamos que este é o valor de $R$. No sistema original, a mesma razāo, a "proporçāo entre o trabalho e os meios de produçāo na economia como um todo" do Sr. Cuevas, é igual a:

$$
\frac{1 x}{p_{0} A x}=\frac{1}{1,2666}=0,7894
$$

e NÂO é, portanto, a "proporçāo crítica". Esta última, no sistema original, é igual como o dissemos, à razāo entre o preço do produto líquido e o preço dos meios de produçāo quando a taxa dos salários é nula. Neste caso, chamando de $\mathrm{p}_{\mathrm{R}} \circ$ vetor dos preços:

$$
\mathrm{p}_{\mathrm{R}}=\left[\begin{array}{lll}
0,9801 & 0,8065 & 0,4286
\end{array}\right]
$$

e com efeito:

$$
\frac{P_{R}[I-A] x}{P_{R} A x}=0,7712
$$

\section{CONCLUSÖES}

Algumas observações finais a respeito da nāo-influēncia das indústrias dos bens nāo-básicos sobre a determinaçāo da taxa de lu cro nāo parecem supérfluas. O Sr. Cuevas propôs-se mostrar que os nāo-básicos afetam esta taxa através da sua influēncia sobre os preços dos básicos (1984:128). Aparentemente encorajado pelos comentários de Kenneth May (1948) a respeito do artigo de Winternitz (1948), ele declara de início que o argumento de Piero Sraffa (a ausēncia das indústrias dos nāo-básicos nāo afeta a taxa de lucro 
nem os preços dos básicos) funda-se sobre um "erro lógico", e é na verdade uma "hipótese implícita" (Cuevas, 1984:124). Vimos o que pensar da demonstração do Sr. Cuevas: é nela que encontramos o erro lógico. A incorreção desta não implica, no entanto, que tenhamos mostrado que a proposição de Piero Sraffa é fundada. Porém, o exame de um sistema de preços de produção incluindo básicos e não-básicos dissipa imediatamente qualquer dúvida. A matriz dos coefí cientes técnicos, neste caso, é decomponível, e, portanto:

$$
p=p A(1+r)+w 1 \Longleftrightarrow\left\{\begin{array}{l}
p^{1}=p^{1} A_{1}^{1}(1+r)+w l_{1} \\
p^{2}=\left[p^{1} A_{1}^{2}+p^{2} A_{2}^{2}\right](1+r)+w l_{2}
\end{array}\right.
$$

se a matriz $\mathrm{A}$ é reordenada de maneira que:

$$
A=\left[\begin{array}{ll}
A_{1}^{1} & A_{1}^{2} \\
0 & A_{2}^{2}
\end{array}\right]
$$

A taxa de lucro $\mathrm{r}$ e os preços $\mathrm{p}^{1}$ dos bens básicos dependem da tecnologia nas indústrias dos básicos e da taxa dos salários w; a tecnologia dos bens não-básicos permite então o cálculo dos preços destes, $\mathrm{p}^{2} . \mathrm{Il}^{\prime}$

Sabemos, após o trabalho fundamental de Piero Sraffa, que, pa ra calcular os preços de produção, a distinção pertinente é aquela entre produtos básicos e não-básicos ao nível de uma desagregação completa da tecnologia (de um "mapa 1:1" dos métodos de produção). Se há produtos não-básicos em um sistema econômico - entende-se aqui por sistema uma tecnologia postulada -, então é EXPLICITAMENTE postulado que a produção dos básicos independe da dos não-básicos. Isto implica logicamente o argumento de Piero Sraffa. Ao contrário

1 As condições de existēncia de preços todos positivos podem ser exatamente especificadas, e interpretadas do ponto de vista econōmico. Ver a respeito o artigo exaustivo de Paolo Varri (1979). Uma apresentaçāo sumäria destas condi çōes encontramse também em Pasinetti (1977:104-111). 
de uma hipótese implícita mascarada em uma lógica incorreta, temos uma lógica perfeita decorrente de uma hipótese explícita. E nossa opiniāo que Kenneth May dificilmente discordaria de Sraffa; efetuando as devidas adaptações em funçāo do contextc teórico diferen te, nāo declararia ele que "a independēncia do lucro decorre da fórmula" (May, 1948:599)? O Sr. May merece também, afinal, leito res menos apressados.

Convenhamos que um argumento algébrico carece de justificativas econômicas. Para eliminar esta possivel crítica, é ainda neces sário dispormos de uma teoria econômica da formaçāo dos preços de produçāo. o assunto é, no mínimo, controvertido. Suspeitando, nāo-obstante, que a maior resistēncia ao argumento de Piero sraffa pro vém dos mais ortodoxos entre os chamados "marxistas fundamentalistas" - o artigo do Sr. Cuevas pode servir de ilustraçāo -, adoteros como teoria da formaçāo dos preços de produçāo a única problemática convincente da transformaçāo dos valores em preços ${ }^{\prime}$. Proposta originalmente por Okishio (1972), ela consiste em obter os preços de produçāo como resultado de um processo iterativo de modificações dos freços iniciais (preços proporcionais aos valores-trabalhol através da aplicaçāo de uma taxa de lucro iterativamente calculada (isto é, recalculada para cada alteraçāo dos preços no decorrer do processo de iteraçāol. Este procedimento consiste, em ou tras palavras, em considerar que a transformaçāo proposta por Marx é a primeira etapa de um processo iterativo que deve ser repetido. okishio (op. cit.) mostrou que o processo converge em direçāo aos preços de produçāo. Mutatis mutandis, o mesmo processo permite obter os preços de produçāo em um modelo sraffiano, no qual os salários nāo fazem parte do capital adiantado, sendo pagos pos-festum.

Queremos entāo sublinhar o resultado seguinte: a taxa de lucro de equilíbrio, resultado deste processo iterativo - aqui inter pretado como teoria econômica da formaçāo dos preços de produçāo -,

2 Convincente enquanto teoria econômica, para um "fundamentalista". Ver Shaikh (1977) para uma argumentação competente. Esta problemática, porém, levanta graves dificuldades de interpretaçāo em um contexto mais amplo, nomeadamente, hả uma transformaçāo "histörica"? 
será a mesma, quer se considere unicamente o conjunto das indústrias dos básicos, quer se considere o conjunto de todas as indústrias.. Isto é, a presença ou ausēncia das indūstrias dos nāo-bāsi cos nāo afeta a taxa de lucro resultando do processo de formaçāo dos preços.

Intuitivamente, a chave para a compreensāo deste resultado aparece se considerarmos o papel diferente dos básicos e dos nāo-bá sicos enquanto insumos. Tomemos o conjunto das indústrias dos bási cos. Ele apresenta uma particularidade: o preço de cada produto é afetado pelo preço de todos os demais. Este bloco de indústrias é tal que o efeito diferencial das taxas de lucro transitórias, ao longo do processo iterativo, sobre o preço de cada produto - mediante a tecnologia especifica de cada -, se repercute sobre os preços de todos os demais produtos. Esta propriedade é restrita ao conjunto das indústrias dos básicos, pela prōpria definiçāo do caráter básico de um produto. Neste sentido, e lembrando a produtivi dade postulada da matriz A dos coeficientes de produçāo, é indife rente, para os preços de produçāo finais e a taxa de lucro de equi líbrio, que as taxas de lucro transitórias sejam calculadas somente no conjunto das indústrias dos básicos ou no conjunto de todas as indústrias. $3 /$ Nas duas eventualidades, as taxas de lucro e os preços transitórios sāo diferentes, mas a taxa de lucro final e os preços finais dos básicos sāo os mesmos. As modificações no traçado do caminho de convergēncia nāo afetam o resultado final. $4 /$ pode mos assim compreender que as condições de produçāo dos bens nāo-bā sicos nāo influenciam a determinaçāo da taxa de lucro

quando o processo de transformaçāo esboçado por Marx é repetido: a mais-valia das indūstrias dos nāo-básicos nāo afeta a determinaçāo da taxa de lucro geral.

3 Isto è, é indiferente que a taxa de lucro, para cada iteraçāo, seja a razāo entre o preço do produto líquido diminuído dos salärios e o preço dos meios de produção para o conjunto das indústrias dos básicos; ou a mesma razào para o conjunto de todas as indústrias.

4 Efetuamos os cálculos iterativos a partir do nosso exemplo ilustrativo, supra. A partir da sexta iteração, a convergencia aparece, quer se considere so mente as indústrias dos bảsicos, que se considere todas. Nos dois casos, preços dos básicos e taxa de lucro tendem a serem iguais. 
Esta arqumentaçāo, pensamo-nos, é idēntica àquela proposta pelo Professor Okishio no quadro de um exemplo simples com trēs in dústrias (Okishio, 1974:6-9). Uma demonstraçāo formal deste resultado, a nosso conhecimento, nāo foi ainda oferecida; mas a reformu laçāo da demonstraçāo da convergēncia no caso de uma tecnologia in decomponivel, proposta pelo Professor Okishio (1972), desta vez a partir de uma matriz dos coeficientes de produçāo decomponível, a permitiria. Um argumento econômico - e nāo puramente algébrico -, no quadro de uma problemática de transformaçāo à la Marx, corrobora a proposiçāo do Sr. Sraffa. 
CUEVAS (1984) Homero. "On Snaffa's Staridand Commodity and the Rate -f Probit", Revista de Econometria 4, pp. 123-132.

MAY (1948) Kenneth. "Value and Prices of Production: A Note on win ternitz's Solution", Economic Journal 58, pp. 596-599.

OKISHIO (1972) Nobuo. "On Marx's Production Prices" (em japonēs), Keizaigaku - Kenyu, Kobe University, 19 (traducào inglesa: "Value and Production-Price", Kobe University Economic Review 20, 1974 , pp. 1-19).

PASINETTI (1977) Luigi L. Lectures on the Theory of Production, New York, Columbia University Press, pp. XIV-285.

SHAIKH (1977) Anwar. "Marx's Theory of Value and the "Transformation Problem": em Schwartz, Jesse, org., The Subtle Anatomy of Capitalism, Santa Monica, Goodyear Publishing Company, 1977, pp. 106-139.

SRAFFA (1960) Piero. Production of Commodities by Means of Comodi ties, Cambridge, Cambridge University Press, pp. XII-99.

VARRI (1979) Paolo. "Basic and Non-basic Commodities in Mr. Sraffa's Price System", Metroeconomica 31, pp. 55-72.

HINTERNITZ (1948) J. "Values and Prices: A Solution of the so-called Trans formation Problem", Economic Journal 58, pp. 276-279. 
